\title{
Protein Kinase C-Dependent and -Independent Effects of Phorbol Esters on Hippocampal Calcium Channel Current
}

\author{
Diane Doerner, ${ }^{1}$ Maha Abdel-Latif, ${ }^{2}$ Terry B. Rogers, ${ }^{2}$ and Bradley E. Alger ${ }^{1}$ \\ 'Department of Physiology, and 'Department of Biological Chemistry, University of Maryland School of Medicine, \\ Baltimore, Maryland 21201
}

Despite their widespread use in investigations of protein kinase $\mathbf{C}(\mathrm{PKC})$, concern is often expressed regarding the specificity of action of phorbol esters. We have extensively compared the effects of PDBu, a phorbol ester that activates PKC, with those of its inactive analog, $4 \alpha-P D B u$, on calcium (Ca) channel regulation in acutely isolated guinea pig hippocampal neurons and found that PKC-dependent and -independent actions could be clearly distinguished. While both phorbol esters depressed whole-cell barium current through Ca channels $\left(I_{\mathrm{Ba}}\right)$, PDBu was approximately 100 -fold more potent than $4 \alpha$-PDBu. PKC-independent effects began to appear in the range of 5-10 $\mu \mathrm{M}$, doses that, while high, have been used in some investigations. Moreover, only PDBu (1) was active when applied intracellularly, (2) had effects that were blocked by the PKC inhibitor $\mathrm{H}-7$, and (3) induced PKC translocation with potency similar to its potency in depressing $I_{\mathrm{Ba}}$. The finding that $4 \alpha-\mathrm{PDBu}$ acted only extracellularly was unexpected and suggested either that it acted via an extracellular binding site or that its orientation in the membrane was crucial to its effects on $\mathrm{Ca}$ channels. Finally, (4) PDBu alone caused a hyperpolarizing shift in the voltage dependence of the high-voltage-activated, rapidly inactivating ( $\mathrm{N}$ type) component of $\mathrm{Ca}$ current. This result extends our previous finding that the $\mathrm{N}$-type current component was depressed by PDBu to a greater extent than the L-type component and may represent an important new mode of neu. rotransmitter regulation of ion channels in the brain via PKC.

Protein kinase $\mathrm{C}(\mathrm{PKC})$ is a ubiquitous enzyme in the nervous system (Nishizuka, 1984; Dell'Aquila et al., 1987). Among its many possible roles is the regulation of neuronal excitability via phosphorylation of ion channel proteins. Investigations of the role of PKC often make use of the exogenous PKC activators, phorbol esters (Castagna et al., 1982; Nishizuka, 1986; Dell'Aquila et al., 1987). Phorbol esters affect neuronal ionic conductances in invertebrates (DeRiemer et al., 1985a, b; Strong et al., 1987; Alkon and Rasmussen, 1988; Alkon et al., 1988)

Received Nov. 5, 1989; revised Nov. 24, 1989; accepted Nov. 30, 1989

This work was supported by NIH Grants HL28138 (T.B.R.) and NS22010 (B.E.A.), an award from the Maryland Biotechnology Center (B.E.A.), IJSPHS Training Grant HL-07612, and the Short Term Research Training Program of the University of Maryland (D.D.). T.B.R. is the recipient of a Research Career Development Award. We thank Dr. Bruce K. Krueger for his comments on a draft of the manuscript.

Correspondence should be addressed to Bradley E. Alger, Ph.D., Department of Physiology, University of Maryland School of Medicine, 660 West Redwood Street, Baltimore, MD 21201.

Copyright (C) 1990 Society for Neuroscience $0270-6474 / 90 / 051699-08 \$ 02.00 / 0$ and vertebrates (Baraban et al., 1985; Malenka et al., 1986a; Rane and Dunlap, 1986). PKC is strongly implicated in mediating phorbol ester effects in invertebrates, but this is less certain in vertebrate neurons. One problem is that some phorbol ester effects may not be PKC mediated (Nishizuka, 1984). For example, it has recently been suggested that phorbol ester and diacylglycerol modulation of calcium (Ca) current in dorsal root ganglion (DRG) cells, first demonstrated by Rane and Dunlap (1986) might not be mediated by PKC (Hockberger et al., 1989). A method often used to assess the specificity of action of phorbol esters has been to apply inhibitors to block the enzyme (Conn et al., 1989; Rane et al., 1989). In hippocampal cells we have found that several inhibitors (Doerner et al., 1988b), including a specific peptide inhibitor (Doerner et al., 1988a) do block phorbol ester effects on Ca channels. A converse approach is to ask if PKC-independent effects of phorbol esters can clearly be demonstrated. While it is possible that the effects of high concentrations of phorbol esters are $\mathrm{PKC}$ independent, dose ranges and other distinctions between specific and nonspecific effects have not been clearly established. PKC is present in especially high levels in mammalian hippocampal neurons (Worley et al., 1986; Nishizuka, 1988) and is thought to have important functional roles, including an involvement in long-term potentiation (Akers et al., 1986; Malenka et al., 1986b; Malinow et al., 1988) and regulation of ionic conductances (Baraban et al., 1985; Malenka et al., 1986a). Phorbol esters have been widely used as probes to implicate PKC in these phenomena. Accordingly, it is crucial to know whether the basic assumption regarding their mechanism of action is correct.

We have used phorbol esters to assess the role of PKC in the hippocampus, and our data indicated that $\mathrm{PKC}$ regulates ionic conductances there (Doerner et al., 1988b). However, an important prediction of the hypothesis that phorbol esters act via $\mathrm{PKC}$ is that there should be a clear distinction between the effects of phorbol esters that do, and those that do not, activate PKC, i.e., between "active" and "inactive" phorbol esters. This prediction has not been tested in detail. To test the hypothesis and extend our investigation of $\mathrm{PKC}$, we have extensively compared the actions of the active phorbol ester, PDBu, with those of its inactive isomer, $4 \alpha-\mathrm{PDBu}$. We used electrophysiological and biochemical methods to address the following specific questions: Can inactive phorbol esters influence ion channel activity and, if so, over what dose range? Is it possible to discriminate between PKC-dependent and -independent actions of phorbol esters? Are phorbol esters effective when applied intracellularly? How do the electrophysiological and biochemical dose-response curves for phorbol-ester-induced activation of PKC compare? 
Our data are consistent with the hypothesis that certain phorbol esters do act via PKC to decrease Ca channel current. Further results reveal that the $4 \alpha$ analog of $\mathrm{PDBu}$ can decrease $\mathrm{Ca}$ current as well. We report for the first time that both PKC-dependent and -independent phorbol ester actions can be distinguished in a given neuronal preparation. Most of these results have been reported in abstract form (Doerner and Alger, 1989).

\section{Materials and Methods}

Electrophysiological studies. Acutely isolated pyramidal neurons were prepared from juvenile guinea pig hippocampus according to the methods of Kay and Wong (1986). Following dissection of one hippocampus from the brain, tissue chunks $\left(1 \mathrm{~mm}^{3}\right)$ were prepared and placed into a buffered saline solution containing $1.8 \mathrm{mg} / \mathrm{ml} \mathrm{DPCC}$-trypsin, where they were gently agitated for $2-3 \mathrm{hr}$. The enzyme solution was then changed for one without enzyme. One or 2 chunks were removed, washed, and triturated through fire-polished pipettes, and the resulting suspension was poured into a polylysine-coated tissue-culture dish. Cells were studied from 10-90 min after dissociation.

The extracellular solution contained (in $\mathrm{mM}$ ) $\mathrm{NaCl}, 125 ; \mathrm{BaCl}_{2}, 2-10$; TEA, $10 ; \mathrm{CsCl}, 5 ; \mathrm{MgCl}_{2}$, 2; HEPES, 10 (pH 7.4); glucose, 10; and 0.001 TTX. All experiments were done at room temperature $\left(20-22^{\circ} \mathrm{C}\right)$.

Whole-cell currents were recorded under tight-seal voltage clamp (Hamill et al., 1981), using a Dagan 8900 clamp or an Axopatch 1C (Axon Instruments). Low-resistance patch electrodes (2-5 M $)$ were filled with (in mM) $\mathrm{CsCH}_{3} \mathrm{SO}_{3}, 145$; HEPES, 10; $\mathrm{MgATP}, 5$; EGTA or BAPTA, $11 ; \mathrm{CaCl}_{2}, 1$; TEA, 10; and leupeptin, 0.1.

Data were digitized at $40 \mathrm{kHz}$, sampled at $1 \mathrm{kHz}$ and stored on mícrocomputer disk using the pClamp system (Axon Instruments). Experimental values are given as mean \pm SEM. In some experiments tai currents following an activation step were measured beginning 350-700 $\mu \mathrm{sec}$ after a postpulse voltage command to $-80 \mathrm{mV}$. Tail currents were well fit by a single-exponential function using pClamp. Peak $I_{\mathrm{Ba}}$ tail current was measured by extrapolation of the exponential to the onset of the postpulse.
The spontaneous decline ("rundown") of Ca currents is a widely observed phenomenon. Rundown can be reduced, but not prevented, by use of $\mathrm{Ba}^{2+}$ rather than $\mathrm{Ca}^{2+}$ as the charge carrier and by the presence of $\mathrm{Mg}$-ATP inside the cell. Under control conditions $I_{\mathrm{Ba}}$ typically runs down at approximately $2.5 \% / \mathrm{min}$. To control for this factor, in each cell we determined the steady rate of rundown that occurred over a period of 3-5 $\mathrm{min}$ in control and linearly extrapolated it. Values of $\mathrm{Ca}$ current depression were determined as the difference between measured amplitudes and the amplitudes predicted by this rate of decline. This is a conservative procedure and produces more reliable results than computing percent depression relative to a fixed control value.

$P K C$ measurement. Hippocampal cells cultured from 17- to 19-d-old fetal rats were grown in dissociated tissue culture according to conventional methods (Segal, 1983). Cells were seeded onto $10 \mathrm{~cm}$ plates and used between the age of 10 and $14 \mathrm{~d}$ in culture. At the time of the experiment, the medium was removed, and the cells were washed with $10 \mathrm{ml}$ of $10 \mathrm{~mm}$ Tris- $\mathrm{HCl}, \mathrm{pH} \mathrm{7.4}$. Cells were then removed by gentle scraping in $1 \mathrm{ml}$ of buffer A (10 mM Tris- $\mathrm{HCl}, 0.5 \mathrm{~mm}$ EGTA, $2 \mathrm{~mm}$ EGTA, $25 \mu \mathrm{g} / \mathrm{ml}$ leupeptin, $\mathrm{pH}$ 7.4) and homogenized in a Teflon-glass homogenizer. The homogenate was centrifuged in a Beckman Airfuge, type A-95 rotor, at $178,000 \times g$ for $10 \mathrm{~min}$. The supernatant (cytosolic fraction) and the pellet (particulate fraction) were then separated. The particulate fraction was resuspended in $1 \mathrm{ml}$ of buffer $A$ to which was added $1 \%$ Nonident NP-40 and incubated for $1 \mathrm{hr}$ on ice. Following centrifugation, the detergent extract from the particulate fraction, as well as the cytosolic fraction, was applied to $1 \mathrm{ml}$ columns packed with Whatman DE-52 cellulose. The columns were then washed with $2 \times 3$ $\mathrm{ml}$ of $20 \mathrm{~mm}$ Tris- $\mathrm{HCl}, 2 \mathrm{~mm}$ EDTA, $0.5 \mathrm{~mm}$ EGTA. The PKC-enriched fraction was eluted with $1 \mathrm{ml}$ of $20 \mathrm{~mm} \mathrm{NaCl}$ in $10 \mathrm{~mm}$ Tris-HCl. The eluted fractions from both the cytosol and the particulate fraction were used in the assay for PKC activity. The PKC assay reaction was performed as previously described (Thomas et al., 1987). PKC activity was defined as the phosphatidylserine, 1,2-dioleoyl-sn-glycerol-stimulated incorporation of ${ }^{32} \mathrm{P}$ from $\left[\gamma_{-}{ }^{32} \mathrm{P}\right] \mathrm{ATP}$ into histone. The assay was linear with 3-6 $\mu \mathrm{g}$ protein from the cytosolic fraction and with $0.4-3 \mu \mathrm{g}$ of protein from the detergent extract of the particulate fraction.

Drugs and chemicals. Unless noted otherwise, all drugs were obtained from Sigma Chemical Corp. (St. Louis, MO). Leupeptin was obtained

A

1 $200 \mathrm{nM}$ PDEu

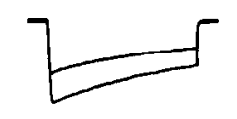
$50 \mathrm{~ms}$
2
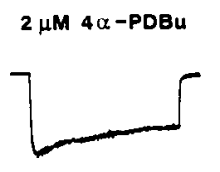

100 PA
3

$50 \mu M 4 \alpha-P D B u$

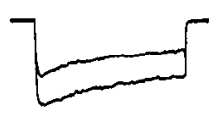

| 300 PA
B.

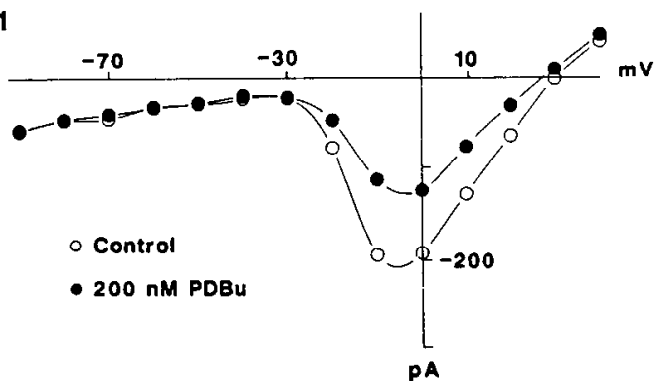

$B_{2}$

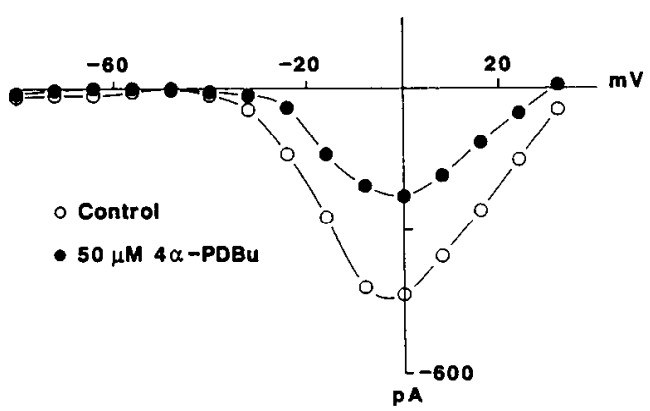

Figure 1. Both active and inactive isomers of PDBu depress $I_{\mathrm{Ba}} . A$, Approximately 10 min after establishment of a whole-cell recording, $I_{\mathrm{Ba}}$ was recorded for several minutes before applying a phorbol ester at the time indicated by the bar along the top of the graph. $B$, Complete currentvoltage plots for 2 cells (different from $A$ ) treated with $200 \mathrm{nM}$ PDBu $(B 1)$ and $50 \mu \mathrm{M} 4 \alpha-\mathrm{PDBu}(B 2)$. 

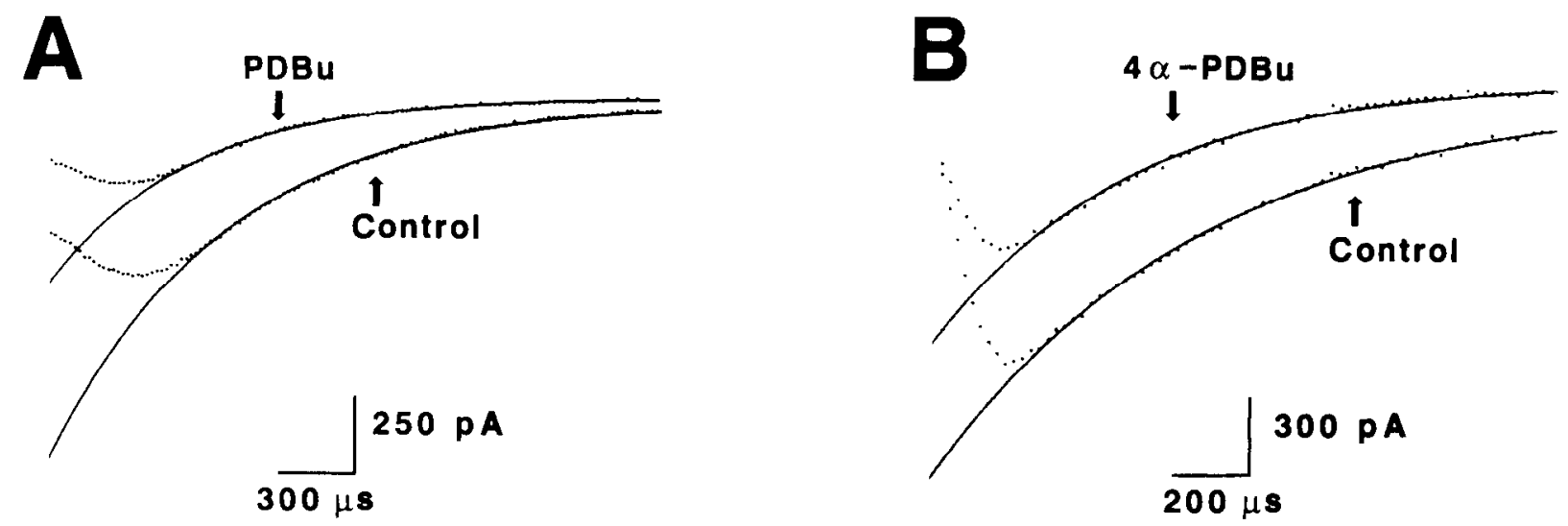

Figure 2. Phorbol esters depress $I_{\mathrm{Ba}}$ tail currents. Examples of tail currents measured in control solution and either $200 \mathrm{nM}$ PDBu $(A)$ or $50 \mu \mathrm{M}$ $4 \alpha$-PDBu $(B)$. Tail currents were recorded at $-80 \mathrm{mV}$ following an activation step to $+10 \mathrm{mV}$. The decay of the current was fit by a single exponential in each case (smooth curves). Time constants were as follows: $A$, control, $640 \mu \mathrm{sec}, \mathrm{PDBu}, 580 \mu \mathrm{sec} ; B, \mathrm{control}, 680 \mu \mathrm{sec}, 4 \alpha-\mathrm{PDBu}$, $730 \mu \mathrm{sec}$.

from Boehringer-Mannheim (Indianapolis, IN) and 1-(5-isoquinolinylsulfonyl)-2-methylpiperazine (H-7) from Seikagaku America (St. Petersburg, FL) as well as from Sigma. Phorbol esters (L.C. Services, Woburn, MA, and Sigma) were dissolved in DMSO, divided into aliquots, and stored frozen until use. As shown in the text, DMSO in concentrations below $0.5 \%$ had no effect on cell properties. Drugs not added to the recording pipcttc werc added dircetly to the static recording chamber in known concentration and volume.

\section{Results}

Whole-cell voltage-clamp recordings of Ca current were carried out in acutely isolated guinea pig hippocampal neurons according to the methods of Kay and Wong (1986). Calcium current was found to be TTX-and $\mathrm{Na}^{+}$-insensitive, carried by $\mathrm{Ba}^{2+}$, and blocked by $\mathrm{Cd}^{2+}$. Unless noted otherwise, cells were held at -50 or $-60 \mathrm{mV}$ to inactivate transient current and were stepped to various test potentials. Multiple $\mathrm{Ca}$ channel types have been reported in hippocampal ncurons (Bley ct al., 1987; Yaari et al., 1987; Doerner et al., 1988b; Tsien et al., 1988); however, the relationship between the channel types and the macroscopic $\mathrm{Ca}$ currents remains uncertain (Kay and Wong, 1987). In most experiments, therefore, we used voltage-clamp protocols designed to isolate the "L" type current; however, in the experiments illustrated in Figures 3 and 4, more than one channel type may have been aclivated (see Discussion). (Note: we use the designations "L" and "N" purely as operational definitions for the slowly and rapidly inactivating components of highvoltage-activated Ca current, respectively, pending single-channel studies.) Bath application of $200 \mathrm{~nm} P D B u$, an active phorbol ester, depressed $\mathrm{Ba}^{2+}$ current through Ca channels $\left(I_{\mathrm{Ba}}\right)$ (Fig. $1 \mathrm{~A}$, open circles). The inactive PDBu isomer at $2 \mu \mathrm{M}$ had no effect (Fig. 1 $A$, filled circles), but in the example shown at a higher concentration, $50 \mu \mathrm{M}$, it clearly depressed $I_{\mathrm{Ba}}$ (Fig. $1 A$, filled triangles). Both forms of $\mathrm{PDBu}$ reduced $I_{\mathrm{Ba}}$ throughout its range of activation without altering the shapes of the $I-V$ plots (Fig. 1, B1, B2).

Despite the similarities apparent in Figure $1 A$, the effects of PDBu and $4 \alpha$-PDBu were not identical. A qualitative difference was revealed in an examination of the voltage dependence of steady-state inactivation and activation of $I_{\mathrm{Ba}}$. To avoid contamination with current through $\mathrm{K}$ channels, maximum $I_{\mathrm{Ba}}$ was taken as the peak value of the tail current measured at $-80 \mathrm{mV}$, extrapolated from a single-exponential function (Fig. 2). Phorbol esters do not alter the time constant of deactivation (Doerner et al., 1988b). Activation and inactivation were measured using voltage-clamp protocols indicated in Figure 3. After delivering the voltage protocols in control and then in phorbol ester-containing medium, the Ca current was further isolated by subtracting currents elicited by an identical series of voltage steps after bath application of $500 \mu \mathrm{M} \mathrm{Cd}^{2+}$ from the net current

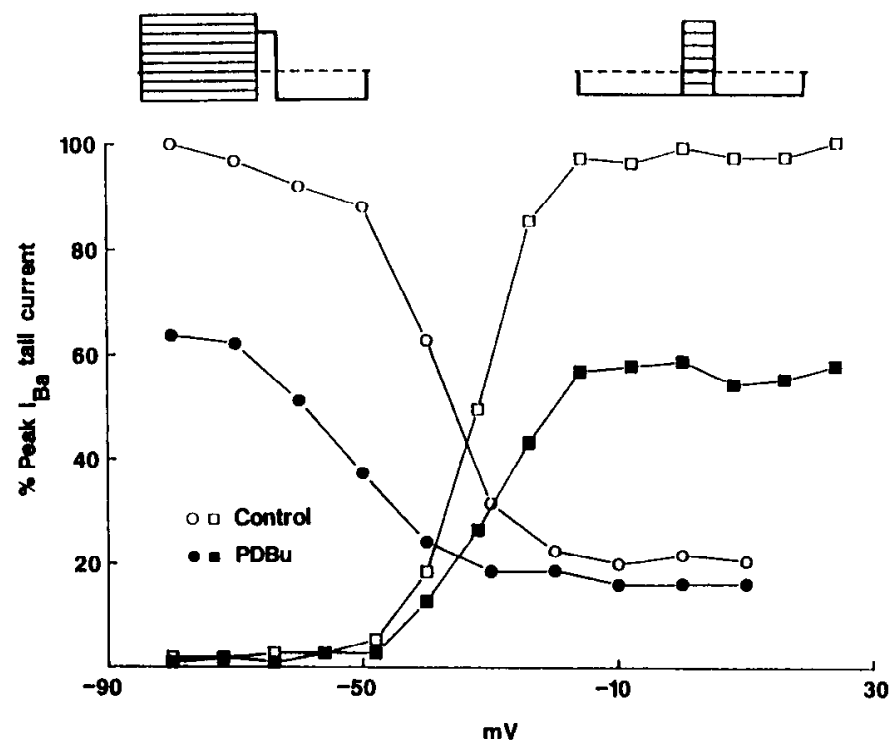

Figure 3. Phorbol ester effects on voltage dependence of activation and inactivation of $I_{\mathrm{Ra}}$. Inactivation was determined using the protocol shown at top left. The cell was stepped for $2.5 \mathrm{sec}$ to a prepulse potential between -80 and $+10 \mathrm{mV}$. It was then stepped to $0 \mathrm{mV}$ to activate the current for $10 \mathrm{msec}$ and then postpulsed to $-80 \mathrm{mV}$. Following delivery of this series of pulses, PDBu was added to the bath, and, after allowing several minutes for the effects to asymptote, the same series of pulses was delivered. The tail currents, collected at $-80 \mathrm{mV}$, were fit with a single exponential, and peak values were determined by extrapolation to the onset of the postpulse. Activation curves were determined by prepulsing the cell to $-80 \mathrm{mV}$, stepping for $10 \mathrm{msec}$ to potentials between -80 and $+32 \mathrm{mV}$ in $8 \mathrm{mV}$ increments, and finally clamping the cell to $-80 \mathrm{mV}$, at which point the tail current was measured as described above. The results shown were all obtained from a single cell and were typical of the group data (see below). 

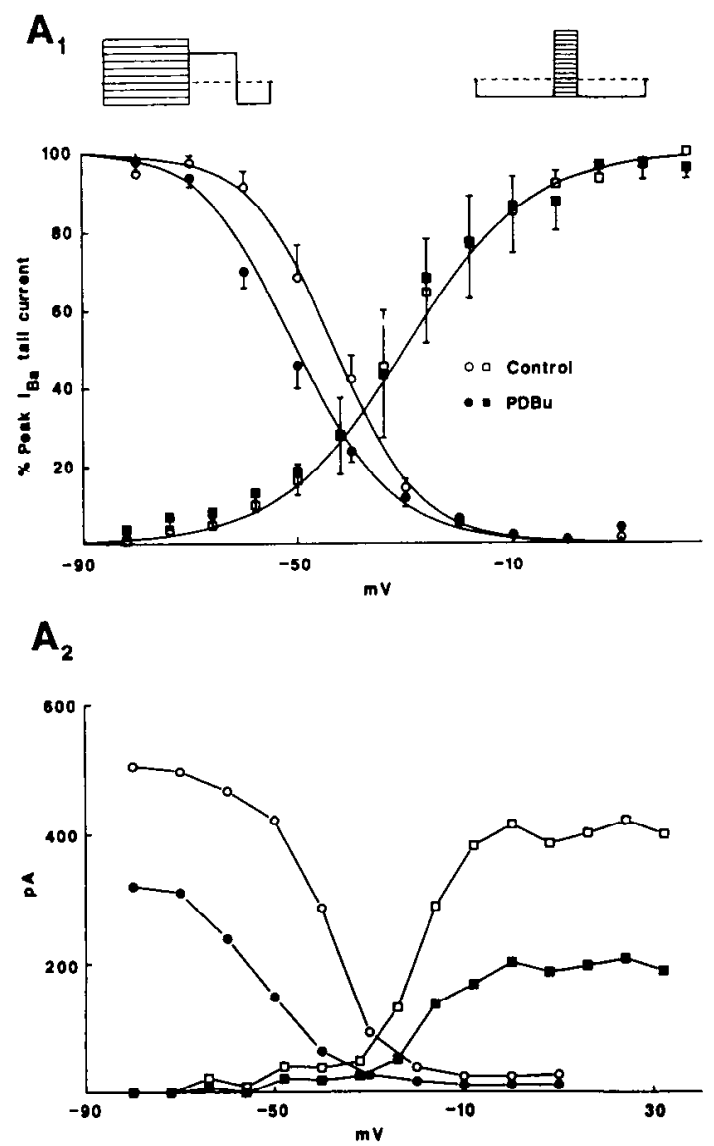

$\mathbf{B}_{1}$

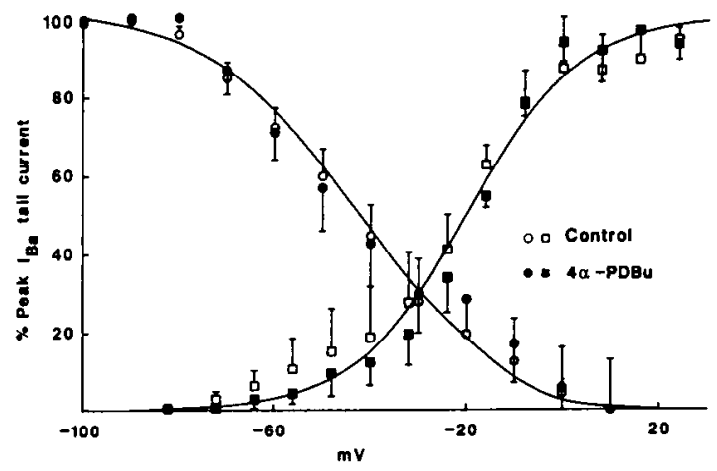

$\mathbf{B}_{2}$

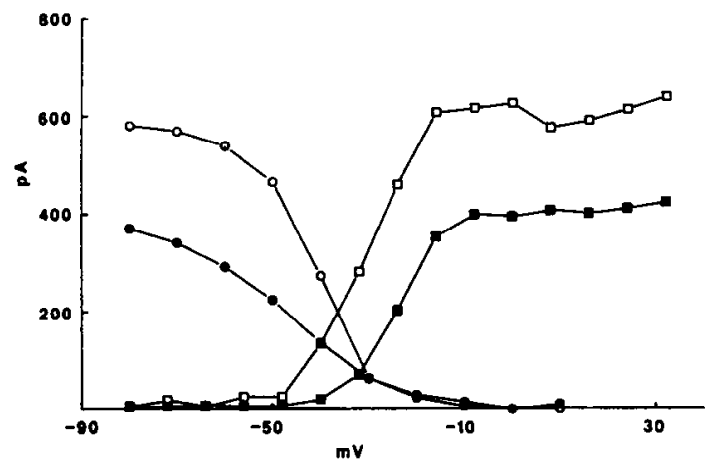

Figure 4. Phorbol ester effects on the initial, inactivating component of $I_{\mathrm{Ba}}$. Voltage-clamp protocols indicated at the top were used, and data were collected as in Figure 3, except that the "noninactivating" component was subtracted before the data were plotted. Points in $A$, and $B$, are means \pm SEM of values from 4 cells each for PDBu and $4 \alpha$-PDBu; one activation and one inactivation curve were obtained from each cell. Identical results were obtained in an additional 3 cells in which slightly different clamp protocols were used. The solid lines are Boltzmann equation fits to the data. The equation for inactivation is $y=1 /\left[1+\exp \left(\left(V-V_{0.5}\right) / k\right)\right]$ and for activation, $y=1 /\left[1+\exp \left(\left(V_{0.5}-V\right) / k\right)\right]$, where $V_{0.5}$ is the voltage at the midpoint of the curve and $k$ is the slope factor. $A_{t}$, Inactivation: control, $V_{1 / 2}=-42.1 \mathrm{mV}, k=7.9 ; \mathrm{PDBu}, V_{1 / 2}=-50.9 \mathrm{mV}, k=9.3$. Activation: control and $\mathrm{PDBu}, V_{1 / 2}=-22.1 \mathrm{mV}, k=12.1$. $B_{\text {, }}$, Inactivation: control and $4 \alpha-\mathrm{PDBu}, V_{1 / 2}=-43.1 \mathrm{mV}, k=14.7$. Activation: control and $4 \alpha-\mathrm{PDBu}, V_{1,}=-20.1 \mathrm{mV}, k=11.6$. The holding potential was $-60 \mathrm{mV}$. Nonnormalized data from 2 typical cells from the groups in $A$, and $\mathrm{B}$, are plotted in the bottom graphs $\left(A_{2}\right.$ and $\left.B_{2}\right)$.

records. Use of these protocols resulted in data such as plotted in Figure 3. A notable feature is the persistence of a current component that did not inactivate at any potential tested. Such a resistant component has been noted by others (Brown and Griffith, 1983; Kay and Wong, 1987) and may reflect the fact that $L$ type channels do not fully inactivate in $2.5 \mathrm{sec}$ (Tsien et al., 1988). Clearly, the voltage-clamp rcgimen elicited both rapidly inactivating and very slowly or "noninactivating" Ca current components perhaps corresponding to $\mathrm{L}$ and $\mathrm{N}$ type currents. In order to investigate possible effects on the activation and inactivation functions, we subtracted the slowly inactivating component and normalized and replotted the data.

PDBu induced a clear leftward shift of the inactivation plots in 7 of 8 cells, while no change was seen in $I_{\mathrm{Ba}}$ activation. There was no change in either activation or inactivation in cells treated with $4 \alpha$-PDBu. Group data are plotted in Figure 4, $A 1, B 1$. The continuous lines through the points are computer-generated fits of the points by the relevant Boltzmann equation. Measured at the midpoint of the inactivation function for the combined data, PDBu caused a hyperpolarizing shift of $9.3 \mathrm{mV}$. Alternatively, fits of the Boltzmann equation to each cell individually produced a mean shift of the inactivation curves of $9.0 \pm 1.3 \mathrm{mV}(n=$

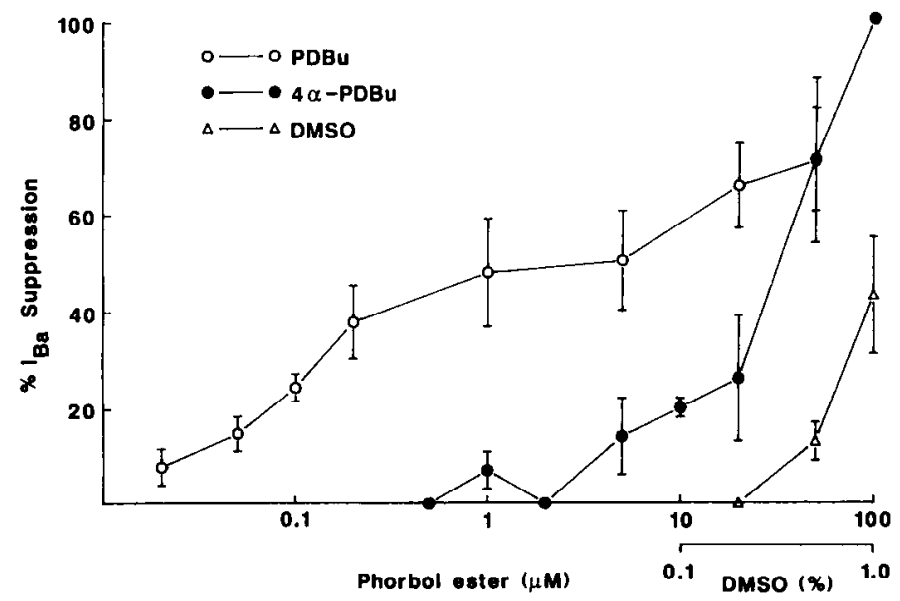

Figure 5. Dose-response data for $\mathrm{PDBu}, 4 \alpha$-PDBu, and DMSO. Points are means \pm SEM from 4-12 cells per point; data have been normalized. The scale for DMSO is aligned with the phorbol ester scale such that the concentration of DMSO normally present with a given concentration of phorbol ester can be read from the DMSO scale; e.g., $0.1 \%$ DMSO is present at $10 \mu \mathrm{M}$ phorbol ester. 
7). Activation data in the same cells could be well described by a single Boltzmann function, as could both inactivation and activation data from cells treated with $4 \alpha-\mathrm{PDBu}$. Analysis of individual cell records indicated a mean difference of less than $1 \mathrm{mV}(n=6)$ in the activation functions in control and PDButreated cells. In principle, an increase in the series resistance of the pipette could explain a shift in the voltage dependence of inactivation. There was no change in series resistance, however, as evidenced by the lack of a comparable shift in the voltage dependence of activation. Both analogs depressed the maximal current, as shown in the examples of Figure $4, A 2, B 2$.

As suggested by Figure $1 A, \mathrm{PDBu}$ and $4 \alpha$-PDBu differed markedly in their potency in reducing $I_{\mathrm{Ba}}$. Figure 5 illustrates this difference in more detail. Threshold effects for PDBu are seen at 10-50 nM. Concentrations of PDBu between $200 \mathrm{~nm}$ and $5 \mu \mathrm{M}$ produced roughly equivalent effects, but concentrations above $10 \mu \mathrm{M}$ produced greater depression. Below 5-10 $\mu \mathrm{M}$ $4 \alpha-\mathrm{PDBu}$ had no effect, whereas $I_{\mathrm{Ba}}$ was reduced in a dosedependent fashion at $4 \alpha$-PDBu doses above $10 \mu \mathrm{M}$. Figure 5 also indicates that "vehicle effects" were seen at DMSO concentrations of $0.5 \%$ and above, the concentrations present with doses of phorbol esters $\geq 50 \mu \mathrm{M}$. Hence, some $I_{\mathrm{Ba}}$ depression at very high concentrations of phorbol esters must be due to DMSO, but DMSO cannot account for all of the effects seen.

PKC is an intracellular enzyme (Nishizuka, 1984), and a bona fide PKC-dependent effect of phorbol esters should be produced by intracellular application of these activators. To test this prediction, we included phorbol esters in the patch recording elec- trode-filling solution in doses of $20 \mathrm{nM}-10 \mu \mathrm{M}$ for PDBu and $50-100 \mu \mathrm{M}$ for $4 \alpha$-PDBu. Inhibitory effects of PDBu on $I_{\mathrm{Ha}}$ were indicated by several observations: (1) in cells where a significant $I_{\mathrm{Ba}}$ was seen, its mean peak amplitude was less than $20 \%$ of that in control cells, (2) the current that did develop with 20 or 50 nм PDBu in the pipette "ran down" at a much faster rate than in control cells (Fig. 6, $A, B$ ), and (3) no net inward current was detected in 5 of 11 cells recorded with electrodes containing 1 $10 \mu \mathrm{M}$ PDBu, as compared with 0 of 10 cells under control conditions or with 0 of 8 cells injected with 50 or $100 \mu \mathrm{M} 4 \alpha-$ $\mathrm{PDBu}$. In cells loaded with $4 \alpha$-PDBu, $I_{\mathrm{B}: \mathrm{a}}$ did not differ from control cells in any of these parameters. To confirm that the $4 c x-$ PDBu was effective in these experiments, we reapplied it at 50 $\mu \mathrm{M}$ to the outside of 4 cells after establishing its lack of effect inside. Figure $6 C$ illustrates a typical experiment.

Several inhibitors of PKC exist (Hidaka et al., 1984; Hannun and Bell, 1987). Even though they are not selective for PKC, a minimal prediction is that they should block a PKC-dependent process. The inhibitor $\mathrm{H}-7,50 \mu \mathrm{M}$, blocked the depressant effect of $200 \mathrm{~nm}$ PDBu but not the effects of $50 \mu \mathrm{M} 4 \alpha$-PDBu (Fig. 7). The effects of $50 \mu \mathrm{M} P D B u$ were only partially prevented by $\mathrm{H}-7$ ( $n=5$; data not shown), as expected if PDBu has PKCindependent effects at high doses.

In order to determine if the phorbol esters activated PKC under the experimental conditions used, we examined the effects of these agents on the intracellular distribution of the enzyme. Translocation of PKC from the cytosol to the particulate fraction was used as an index of enzyme activation. We used cultured

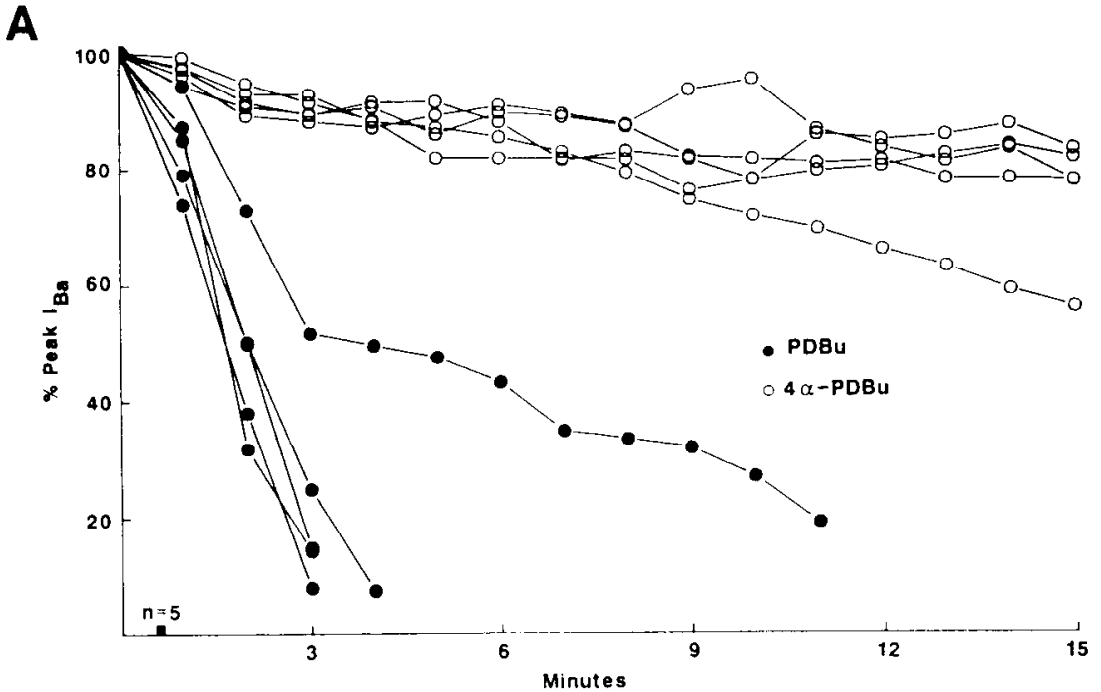

B

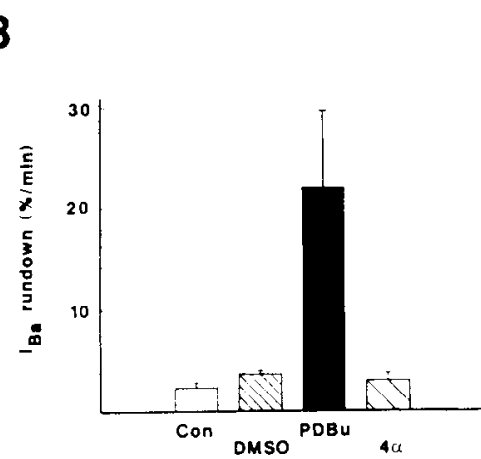

\section{C}

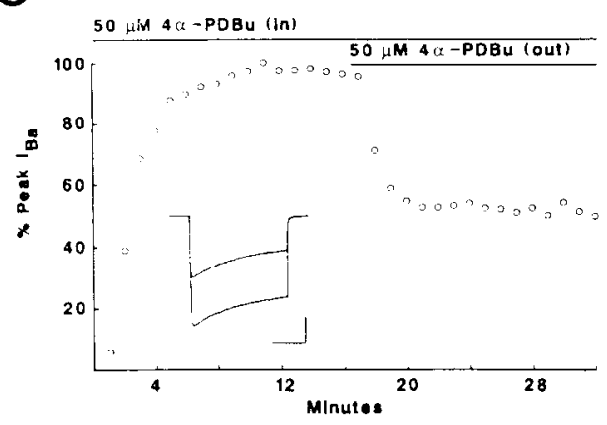

Figure 6. PDBu. but not $4 \alpha-\mathrm{PDB}$. depresses $I_{\mathrm{Ba}}$ when applied intracellularly. Phorbol esters ( 20 or 50 nм PDBu or 50 or $100 \mu \mathrm{M} 4 \alpha$-PDBu) were present in the recording electrodes in addition to normal electrode constituents. $A$, The normalized peak current amplitude achieved following establishment of the whole-cell recording is plotted at time zero. As can be seen, $I_{\mathrm{k} .1}$ "ran down" much more rapidly in the presence of PDBu (filled circles) than in the presence of $4 \alpha-\mathrm{PDBu}$ (open circles). Additionally, in 5 cells recorded with $\mathrm{PDBu}$ containing electrodes $(1-10 \mu \mathrm{M})$, no net inward current developed (filled squar'), an observation never made with $4 x_{-}-$ PDBu. $B$, Histogram depicting the mean rate of rundown for the period $0-3 \mathrm{~min}$ from the data in $A$ for cells in which a net inward current was present. $I_{\mathrm{Ba}}$ rundown in cells recorded with PDBu-containing electrodes was significantly greater than in cells recorded with control electrode solution or with DMSO $(1 \%, n=5)$ or $50 \mu \mathrm{M} 4 \alpha$-PDBu $(n=5)$ in the pipette $(p<0.01$. Student's $t$ test $)$. C. Typical cell recorded with an electrode containing $50 \mu \mathrm{M} 4 \alpha$-PDBu showing that, even when $4 \alpha$-PDBu applied inside a cell had no effect, application of the same concentration outside rapidly depressed $I_{\mathrm{Bu}}$. 


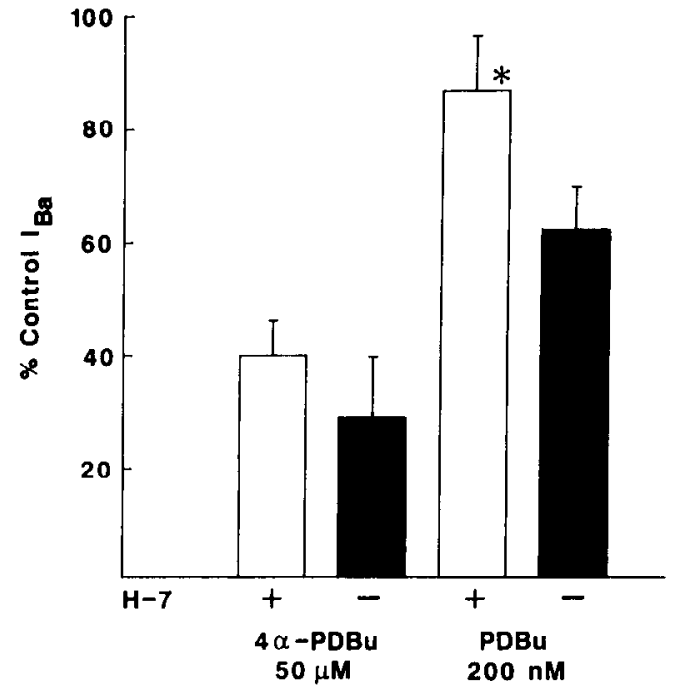

Figure 7. The PKC inhibitor $\mathrm{H}-7$ antagonizes effects of PDBu but not those of $4 \alpha-\mathrm{PDBu}$. Peak depression of $I_{\mathrm{Ba}}$ caused by $200 \mathrm{nM}$ PDBu or $50 \mu \mathrm{M} 4 \alpha$-PDBu after 8 min of treatment, either in the presence $(+)$ or absence $(-)$ of $50 \mu \mathrm{M} \mathrm{H}-7$. H-7 reduced the depression due to $\mathrm{PDBu}$ with no significant effect on the depression due to $4 \alpha-\mathrm{PDBu}[200 \mathrm{nM}$ $\mathrm{PDBu}, n=17 ; 200$ пм PDBu $+50 \mu \mathrm{M} \mathrm{H}-7, n=9 ;{ }^{*} p<0.05 ; 50 \mu \mathrm{M}$ $4 \alpha-\mathrm{PDBu}, n=9 ; 50 \mu \mathrm{M} 4 \alpha-\mathrm{PDBu}+50 \mu \mathrm{M} \mathrm{H}-7, n=5$ (n.s.)].

rat hippocampal neurons to obtain sufficient tissue for biochemical measurements. We have established that PDBu reduces $I_{\mathrm{Ba}}$ in this preparation as well (Doerner et al., 1988b). As shown in Figure $8 A$, in control cells about $75 \%$ of the total enzyme activity was found in the cytosol. When the cells were exposed to $1 \mu \mathrm{M}$ PDBu, there was a redistribution of enzyme activity to the particulate fraction within $20 \mathrm{~min}$. In contrast, there was no translocation of the enzyme when the cells were exposed to $4 \alpha$-PDBu ( $100 \mu \mathrm{M})$ under conditions where it evoked a decrease in channel activity. The dose-response relationship for PDBu-evoked PKC translocation showed that it occurred over the dose range in which it evoked a decrease in $I_{\mathrm{Ba}}$ (Fig. $8 B$ ). The $\mathrm{IC}_{50}$ in both cases is near $50 \mathrm{~nm}$.

\section{Discussion}

Our main findings are that (1) $\mathrm{PDBu}$, at concentrations from 10 to $1000 \mathrm{nM}$, does modify Ca channels in hippocampal neurons via $\mathrm{PKC}$; (2) $4 \alpha$-PDBu, the inactive analog, can also modify Ca channel function; and (3) clear distinctions can be made between PKC-dependent and -independent sites of action of phorbol esters. New evidence that PDBu acts via PKC to depress hippocampal Ca channel function includes observations that it suppresses $I_{\mathrm{Ba}}$ when applied intracellularly and that it causes PKC translocation with a potency very similar to its potency in producing $I_{\mathrm{Ba}}$ reduction. Confirmation of our previous observation that the PKC inhibitor, $\mathrm{H}-7$, blocks PDBu effects further supports the involvement of PKC. Conversely, evidence indicating that $4 \alpha$-PDBu does not act via PKC includes its ineffectiveness when applied to the inside of cells, its insensitivity to $\mathrm{H}-7$ and its inability to translocate PKC. Finally, besides the preceding points, there are additional quantitative and qualitative differences between the effects of active and inactive phorbol esters. PDBu acts at much lower concentrations than does the inactive isomer, and the shift that PDBu induces in the

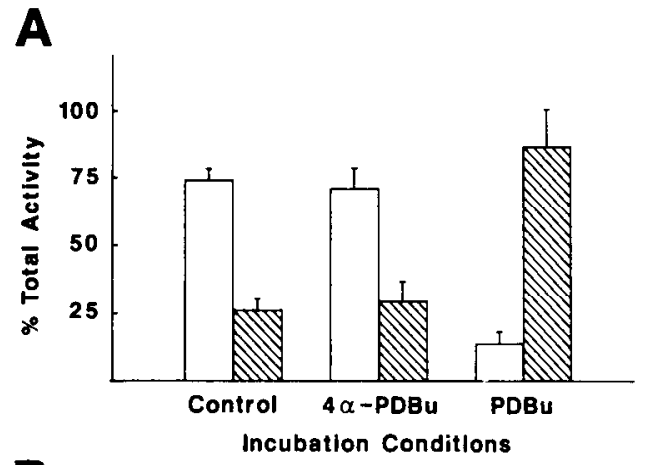

B

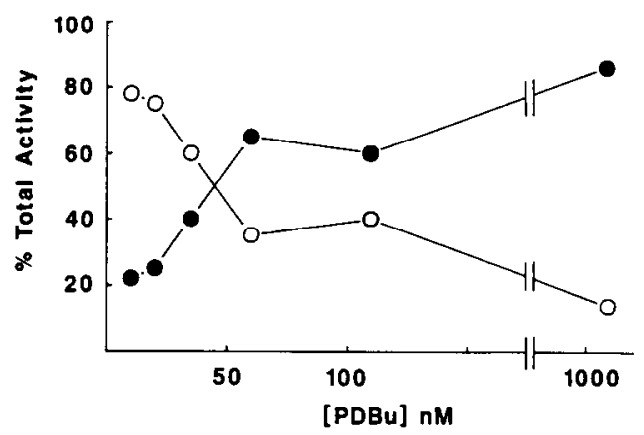

Figure 8. PDBu, but not $4 \alpha-\mathrm{PDBu}$, causes translocation of PKC to the membrane fraction. Effect of PDBu and $4 \alpha$-PDBu on PKC distribution in cultured hippocampal cells. $A$, Cells were incubated with or without $1 \mu \mathrm{M}$ PDBu or $100 \mu \mathrm{M} 4 \alpha$-PDBu for $20 \mathrm{~min}$ in $10 \mathrm{~mm}$ HEPES, $145 \mathrm{~mm} \mathrm{NaCl}, 5 \mathrm{~mm} \mathrm{MgCl}_{2}, 5 \mathrm{~mm} \mathrm{KCl,} 10 \mathrm{~mm}$ glucose, pH 7.4. PKC activity was then assayed in cytosol and particulate fractions as described in Materials and Methods. $B$. Cells were incubated with the indicated concentrations of PDBu for $20 \mathrm{~min}$, after which the cytosol and particulate fractions were assayed for PKC activity. The results are the means of 5 independent experiments \pm SEM. The $100 \%$ values for PKC activity (in nmol ${ }^{32} \mathrm{P}$ incorporated in histones $/ \mathrm{min} / \mathrm{mg}$ protein) were $0.6 \pm 0.2$ and $0.3 \pm 0.2$ for control or $4 \alpha$-PDBu-treated cells in the cytosol and particulate fractions, respcctivcly; and $0.1 \pm 0.1$ and $0.77 \pm 0.6$ for the PDBu-treated cells in the cytosol and membrane fractions, respectively.

voltage dependence of $I_{\mathrm{Ba}}$ inactivation implies that it has a biophysically distinct site of action.

PKC-independent effects of phorbol ester seem to occur in platelets (Nishizuka, 1984), and Hockberger et al. (1989) reported apparent $\mathrm{PKC}$-independent effects of diacylglycerol and phorbol 12-myristate 13-acetate (TPA) on $\mathrm{Ca}^{2+}$ currents in DRG cells. However, Hockberger et al. did not detect any distinction between active and inactive phorbol esters, and it was not established over what dose range PKC-independent effects might be expected. Our data indicate that concentrations of $\mathrm{PDBu}$ above $5 \mu \mathrm{M}$, such as are occasionally used, probably have effects not due to $\mathrm{PKC}$ activation.

A major difference between our data and those of Hockberger et al. (1989) concerns the question of intracellular action of phorbol esters. We found that PDBu was quite effective when applied intracellularly, whereas in DRG cells TPA was ineffective. This difference may in part be related to the unusually high levels of cytosolic PKC found in the hippocampal cells as well as, perhaps, to the differential contribution of particular forms of PKC found in hippocampus, as compared with the other cells (Nishizuka, 1988). Another factor that we considered important 
was the use of PDBu. Not only does its greater hydrophilicity make it easier to use in these experiments than TPA, but also the availability of the $4 \alpha$ form of PDBu provides essentially ideal control for "nonspecific" effects. Interestingly, we found that $4 \alpha$-PDBu was inactive when applied intracellularly. While the intracellular concentration of phorbol esters could not be independently confirmed in these experiments, it is very likely to be very near the concentrations present in the large-bore patch electrodes used, since PDBu was effective in low concentrations and since both isomers should have equal mobility in the cell. These considerations suggest either that the effects of $4 \alpha$-PDBu are mediated by interaction with an extracellular site or that the orientation of $4 \alpha-\mathrm{PDBu}$ in the membrane and, hence its interaction with ion channels, is dependent on its mode of access to the membrane.

Inspection of the dose-response relationship for PDBu suggests that it is biphasic; the depressant effect on $I_{\mathrm{Ba}}$ increases from 10 to $200 \mathrm{nM}$, after which there is relatively little change until concentrations in excess of $10 \mu \mathrm{M}$ are reached, when further depression occurs. On the other hand, clear depressant actions of $4 \alpha$-PDBu are only seen above 5-10 $\mu \mathrm{M}$. The close similarity of structure of $\mathrm{PDBu}$ and $4 \alpha-\mathrm{PDBu}$ and the decreased ability of $\mathrm{H}-7$ to block depressant effects of $50 \mu \mathrm{M}$, as compared with $200 \mathrm{~nm}, \mathrm{PDBu}$ suggest that the depression produced by high concentrations of PDBu is in part due to a PKC-independent effect. The inability of $4 \alpha-\mathrm{PDBu}$ to translocate PKC and the insensitivity of its effects to block by $\mathrm{H}-7$ indicate that $4 \alpha-\mathrm{PDBu}$ effects are not due to contamination of the $4 \alpha$-PDBu with PDBu.

In many cases, transmitter-dependent regulation of voltagedependent $\mathrm{Ca}$ current involves changes in the number of channels activated or in the probability of channel opening (Tsien, 1983). There is little evidence for neuronal Ca current regulation via changes in the voltage dependence of channel activation or inactivation, although PKC affects cardiac $\mathrm{Ca}$ current in this way (Dosemeci et al., 1988). Bean (1989) has reported that in DRG cells certain neurotransmitters can regulate $\mathrm{Ca}$ channel function via shifts in the voltage dependence of $\mathrm{Ca}$ channel activation. In hippocampal cells, the channel type responsible for the inactivating component of high-voltage-activated $\mathrm{Ca}$ current has not been unambiguously identified. Moreover, recent demonstrations of noninactivating or slowly inactivating current mediated by the $\mathrm{N}$ channel in DRG cells have complicated interpretation of macroscopic currents in terms of underlying channel types (Hirning et al., 1988; Lipscombe et al., 1989). Nevertheless, our inactivation data were well fit by single Boltzmann equations, suggesting the involvement of only a single channel type in mediating the inactivating current component. Hence, the simplest explanation for the data illustrated in Figure 4 is that PDBu altered the voltage dependence of inactivation of the channel mediating the rapidly inactivating, $N$ type, current, extending our previous findings that the $\mathrm{N}$ type component was suppressed more profoundly than the $\mathrm{L}$ type component. We stress, however, that we use the terms $N$ and $L$ for convenience, and single-channel studies are necessary to determine if distinct channel types are responsible for $\mathrm{N}$ and $\mathrm{L}$ type current. That regulation can occur via a shift in the voltage dependence of inactivation would be a novel finding in adult mammalian CNS neurons but is in good agreement with the recent observations of Gross and Macdonald (1989) in tissue-cultured cells. Since certain neurotransmittcrs, notably acetylcholine in the hippocampus, both stimulate phosphatidylinositol breakdown
(Fisher and Agranoff, 1986) and reduce Ca current (Gahwiler and Brown, 1987), it is possible that transmitter regulation of Ca channels can be exerted by shifts in the voltage dependence of inactivation. If so, this would represent a new mode of neurotransmitter action, and future studies must be directed towards testing this hypothesis directly.

\section{References}

Akers RF, Lovinger DM, Colley PA, Linden DJ, Routtenberg A (1986) Translocation of protein kinase C activity may mediate hippocampal long-term potentiation. Science 231:587-589.

Alkon DL, Rasmussen H (1988) A spatial-temporal model of cell activation. Science 239:998-1005.

Alkon DL, Naito S, Kubota M, Chen C, Bank B, Smallwood J, Gallant P, Rasmussen $\mathrm{H}$ (1988) Regulation of Hermissenda $\mathrm{K}^{+}$channels by cytoplasmic and membrane-associated C-kinase. J Neurochem 51: 903-917.

Baraban JM, Snyder SH, Alger BE (1985) Protein kinase C regulates ionic conductance in hippocampal pyramidal neurons: electrophysiological effects of phorbol esters. Proc Natl Acad Sci USA 82:25382542.

Bean BP (1989) Neurotransmitter inhibition of neuronal calcium currents by changes in channel voltage dependence. Nature 340:153156.

Bley KR, Madison DV, Tsien RW (1987) Multiple types of calcium channels in hippocampal neurons: characterization and localization. Soc Neurosci Abstr 13:1010.

Brown DA, Griffith WH (1983) Persistent slow inward calcium current in voltage-clamped hippocampal neurones of the guinea-pig. J Physiol (Lond) 337:303-320.

Castagna M, Takai Y, Kaibuchi K, Sano K, Kikkawa U, Nishizuka Y (1982) Direct activation of calcium-activated, phospholipid-dependent protein kinase by tumor-promoting phorbol esters. J Biol Chem 257:7847-7851.

Conn PJ, Strong JA, Kaczmarek LK (1989) Inhibitors of protein kinase $C$ prevent enhancement of calcium current and action potentials in peptidergic neurons of Aplysia. J Neurosci 9:480-487.

Dell'Aquila ML, Warrren BS, de Vries DJ, Blumberg PM (1987) Protein kinase $C$ as the site of action of the phorbol ester tumor promoters. In: Development and recognition of the transformed cell (Greene MI, Hamaoka T, eds), pp 157-185. New York: Plenum.

DeRiemer SA, Strong JA, Albert KA, Greengard P, Kaczmarek LK (1985a) Enhancement of calcium current in Aplysia neurones by phorbol ester and protein kinase C. Nature 313:313-315.

DeRiemer SA, Greengard P, Kaczmarek LK (1985b) Calcium/phosphatidylserine/diacylglycerol-dependent protein phosphorylation in the Aplysia nervous system. J Neurosci 5:2672-2676.

Doerner D, Alger BE (1989) Active vs inactive phorbol ester effects on whole-cell calcium current in hippocampal neurons. Soc Neurosci Abstr 15:178.

Doerner D, Walsh MP, Alger BE (1988a) Role of C kinase and cGMP in regulating guinea pig or rat hippocampal $\mathrm{Ca}$ current: studies with kinase inhibitors. Soc Neurosci Abstr 14:154.

Doerner D, Pitler TA, Alger BE (1988b) Protein kinase C activators block specific calcium and potassium current components in isolated hippocampal neurons. J Neurosci 8:4069-4078.

Dosemeci A, Dhallan RS, Cohen NM, Lederer WJ, Rogers TB (1988) Phorbol ester increases calcium current and simulates the effects of angiotensin II on cultured neonatal rat heart myocytes. Circ Res 62 : 347-357.

Fisher SK, Agranoff BW (1986) Phosphoinositide turnover in the CNS and in neural-related tissues. In: Phosphoinositides and receptor mechanisms (Putney JW, ed), pp 219-243. New York: Liss.

Gahwiler BH, Brown DA (1987) Muscarine affects calcium-currents in rat hippocampal pyramidal cells in vitro. Neurosci Lett 76:301306.

Gross RA, Macdonald RL (1989) Activators of protein kinase C selectively enhance inactivation of a calcium current component of cultured sensory neurons in a pertussis toxin-sensitive manner. $\mathbf{J}$ Neurophysiol 61:1259-1269.

Hamill OP, Marty A, Neher E, Sakmann B, Sigworth FJ (1981) Improved patch-clamp techniques for high-resolution current recording 
from cells and cell-free membrane patches. Pfluegers Arch 391:85100.

Hannun YA, Bell RM (1987) Lysosphingolipids inhibit protein kinase $C$ : implications for the sphingolipidoses. Science 235:670-674.

Hidaka H, Inagaki M, Kawamoto S, Sasaki Y (1984) Isoquinolinesulfonamides, novel and potent inhibitors of cyclic nucleotide dependent protein kinase and protein kinase C. Biochemistry 23:50365041 .

Hirning LD, Fox AP, McCleskey EW, Olivera BM, Thayer SA, Miller RJ, Tsien RW (1988) Dominant role of N-type $\mathrm{Ca}^{2+}$ channels in evoked release of norepinephrine from sympathetic neurons. Science 239:57-61.

Hockberger P, Toselli M, Swandulla D, Lux HD (1989) A diacylglycerol analogue reduces neuronal calcium currents independently of protcin kinasc $C$ activation. Nature 338:340-342.

Kay AR, Wong RKS (1986) Isolation of neurons suitable for patchclamping from adult mammalian central nervous systems. J Neurosei Methods 16:227-238.

Kay AR, Wong RKS (1987) Calcium current activation kinetics in isolated pyramidal neurones of the CAI region of the mature guineapig hippocampus. J Physiol (Lond) 392:603-616.

Lipscombe D, Kongsamut S, Tsien RW (1989) Alpha-adrenergic inhibition of sympathetic neurotransmitter release mediated by modulation of N-type calcium-channel gating. Nature 340:639-642.

Malenka RC, Madison DV, Andrade R, Nicoll RA (1986a) Phorbol esters mimic some cholinergic actions in hippocampal pyramidal neurons. J Neurosci 6:475-480.

Malenka RC, Madison DV, Nicoll RA (1986b) Potentiation of synaptic transmission in the hippocampus by phorbol esters. Nature 321 : 175-177.

Malinow R, Madison DV, Tsien RW (1988) Persistent protein kinase activity underlying long-term potentiation. Nature 335:820-824.
Nishizuka Y (1984) The role of protein kinase $C$ in cell surface signal transduction and tumour promotion. Nature 308:693-698.

Nishizuka Y (1986) Studies and perspectives of protein kinase C. Science 233:305-312.

Nishizuka Y (1988) The molecular heterogeneity of protein kinase C and its implications for cellular regulation. Nature 334:661-665.

Kane SG, Dunlap K (1986) Kinase Cactivator 1,2-oleoylacetylglycerol attenuates voltage-dependent calcium current in sensory neurons. Proc Natl Acad Sci USA 83:184-188.

Rane SG, Walsh MP, McDonald JR, Dunlap K (1989) Specific inhibitors of protein kinase $\mathrm{C}$ block transmitter-induced modulation of sensory neuron calcium current. Neuron 3:239-245.

Segal M (1983) Rat hippocampal neurons in culture: responses to electrical and chemical stimuli. J Neurophysiol 50:1249-1264.

Strong JA, Fox AP, Tsien RW, Kaczmarek LK (1987) Stimulation of protein kinase $C$ recruits covert calcium channels in Aplysia bag cell neurons. Nature 325:714-717.

Thomas TP, Gopalakrishna R, Anderson WB (1987) Ilormone- and tumor-promoter-induced activation or membrane association of protein kinase $C$ in intact cells. Methods Enzymol 141:399-411.

Tsien RW (1983) Calcium channels in excitable cell membranes. Annu Rev Physiol 45:341-358.

Tsien RW, Lipscombe D, Madison DV, Bley KR, Fox AP (1988) Multiple types of neuronal calcium channels and their selective modulation. Trends Neurosci 11:431-438.

Worley PF, Baraban JM, Snyder SH (1986) Heterogeneous localization of protein kinase $\mathrm{C}$ in rat brain: autoradiographic analysis of phorbol ester receptor binding. J Neurosci 6:199-207.

Yaari Y, Hamon B, Lux HD (1987) Development of two types of calcium channels in cultured mammalian hippocampal neurons. Science 235:680-682. 